\title{
Distribution and ecological requirements of ostracods (Crustacea) at high altitudinal ranges in Northeastern Van (Turkey)
}

\author{
Okan Külköylüoğlu ${ }^{1 *}$, Necmettin Sari ${ }^{1}$ and Derya Akdemir ${ }^{2}$ \\ ${ }^{1}$ Department of Biology, Faculty of Arts and Science, Abant İzzet Baysal University, Gölköy, 14280 Bolu, Turkey \\ 2 Department of Biology, Faculty of Arts and Science, Marmara University, İstanbul 34722, Turkey
}

Received 6 September 2011; Accepted 21 September 2011

\begin{abstract}
To understand ostracod distribution and ecology at high altitudes (1659-2889 m a.s.1.), 78 different aquatic sites located in the city of Van were sampled during summer of 2009. A total of 29 ostracod species were recorded in 57 sites. Among the species, Trajancypris laevis (G.W. Müller 1900), is a new report for the Turkish ostracod fauna. First axis of Canonical Correspondence Analysis (CCA) explained about $68 \%$ of the relationships between the 13 most abundant species and environmental variables. Four variables (redox potential, habitat type, $\mathrm{pH}$ and electrical conductivity) had the greatest effect on species composition $(P<0.01)$. Twenty-six species encountered from 38 stations were restricted between 1659 and $1750 \mathrm{~m}$ a.s.l. Above $1750 \mathrm{~m}$ a.s.l., the numbers of species were not significantly affected by altitude $(P>0.05)$. Three species (Heterocypris incongruens (Ramdohr, 1808), Ilyocypris bradyi Sars, 1890 and Potamocypris villosa (Jurine, 1820)) occurred extensively from 1650 to $2350 \mathrm{~m}$ a.s.l. Spearman rank correlation revealed a negative relationship between Limnocythere inopinata (Baird, 1843) and altitude $(r=-0.894, P=0.05)$, while two species (I. bradyi and Prionocypris zenkeri (Chyzer and Toth, 1858)) had a positive correlation to dissolved oxygen $(P=0.05)$. There was a significantly negative relationship between Ilyocypris inermis Kaufmann, 1900 and electrical conductivity, and $H$. incongruens showed a significant correlation to station type. Five groups of species were determined by UPGMA analysis. Species in each cluster were grouped according to ecological conditions suitable for them. Results revealed that species ecological tolerances and optimum levels can be species-specific but species with cosmopolitan distributions tend to have high tolerance ranges to different variables, including altitudinal changes.
\end{abstract}

Key words: Ostracod diversity / high altitude / ecology / optimum and tolerance / distribution / cosmopolitan

\section{Introduction}

Ostracods are small bivalved crustaceans adapted to variety of aquatic habitats ranging from hot springs (Külköylüoğlu et al., 2003) to very cold waters (Delorme, 1991), and spanning a large altitudinal range (Laprida et al., 2006; Külköylüoğlu et al., 2010). Ostracods have been suggested to be important biological indicators of water quality changes (Delorme, 1991) and interspecific variation in habitat preferences suggests that they may play an important role in aquatic food webs (Meisch, 2000). While ostracods are present at high altitudes (e.g., Laprida et al. (2006) described six ostracod taxa from a thermal spring located about $4026 \mathrm{~m}$ a.s.l. in Argentina,

\footnotetext{
*Corresponding author: kulkoyluoglu_o@ibu.edu.tr
}

which is probably the highest altitude ostracods have previously been recorded) little is known about their ecology and distribution at high altitudes. Külköylüoğlu et al. (2011) examined the ecology and distribution of ostracods at locations ranging from 530 to $1095 \mathrm{~m}$ a.s.l. in the Diyarbakır region in eastern Turkey but did not find any clear relationships between species distribution and altitude. However, the upper altitudinal limits of ostracod distribution were not sampled in that study. More generally, reduced species diversity for aquatic species at high altitudes (e.g., insect herbivores, Lawton et al. (1987); copepods, Jersabeck et al. (2001); zoo and phytoplankton, Tolotti et al. (2006); montane diatoms and desmids, Vyverman (1992); amphibians, Pounds et al. (2006)) can be attributed to: (i) lack of suitable habitats, (ii) reduced resource diversity (e.g., lack of large aquatic bodies), 


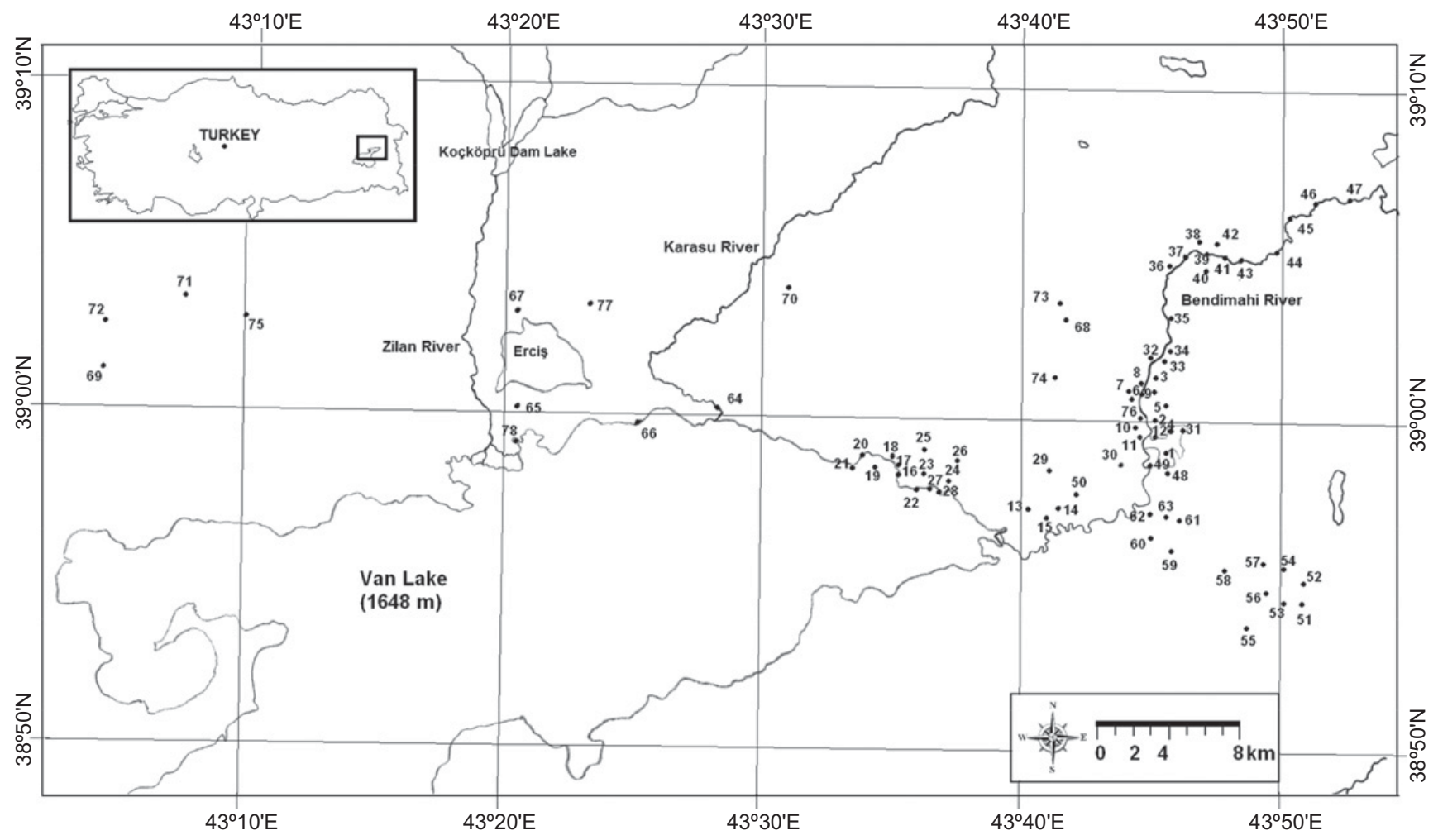

Fig. 1. Total of 78 different sampling sites around and in Northeastern parts of the city Van.

(iii) increasing unpredictable conditions, (iv) climatic changes and (v) difficulty in active and/or passive dispersion (in this study). The ability of a species to occur in any aquatic bodies is limited by its active (i.e., swimming and walking) or passive dispersion (i.e., by means of birds, frogs and fish). Thus, important questions to address regarding ostracod distributions include: (i) How do ostracods extend their distribution up to high altitudes? (ii) What would be the importance of species distribution at those ranges? (iii) How do they tolerate environmental conditions at high altitudes? Based on these questions, the study objectives were (i) to estimate tolerance and optimum levels of individual species, (ii) to examine the ecological requirements of different high altitude species and populations of ostracods, (iii) to determine the distribution of ostracods at high altitudes and (iv) to evaluate whether there were groupings of ecologically similar ostracods along an altitudinal gradient.

\section{Materials and methods}

We measured ten physicochemical environmental variables at 78 randomly selected aquatic bodies during July 2009. Among the sampling sites, we included a variety of different types of aquatic habitats; for example, creeks, springs, ditches, ponds, dams, lakes, troughs, etc. These 78 sites were distributed at altitudes ranging from 1659 to $2889 \mathrm{~m}$ a.s.1. in the Northeastern parts of the city Van, including Lake Van (Fig. 1). At each site, we recorded dissolved oxygen (mg. $\left.\mathrm{L}^{-1}\right)$, percent oxygen saturation (\% Sat.), water temperature $\left({ }^{\circ} \mathrm{C}\right)$, electrical conductivity

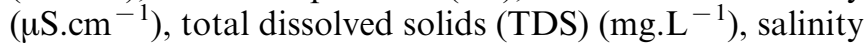
(ppt), redox potential $(\mathrm{mV}), \mathrm{pH}$ and altitude $(\mathrm{m})$. YSI-85 model of oxygen-temperature and HI-98150pH/ORP meters were used to measure values for the first eight variables, while TDS was calculated from electrical conductivity by multiplying it by 0.65 coefficient value (Forester and Brouwers, 1985). The values of Redox potential obtained from the field were transferred to standard hydrogen electrode (SHE). Basic geographic data (e.g., altitude and coordinates) were recorded with a geographical positioning system (GARMIN-GPS 12XL), and air temperature $\left({ }^{\circ} \mathrm{C}\right)$ data were obtained from the Meteorological Station in Van (Appendix 1).

To conduct biological sampling, we used a phytoplankton hand net (200 $\mu \mathrm{m}$ mesh size) to collect samples from each site up to $100 \mathrm{~cm}$ deep. We stored biological samples in $250 \mathrm{ml}$ plastic containers and fixed samples with $70 \%$ ethyl alcohol in situ. In the laboratory, all material was filtered via four standard sieves $(1.5,1.0,0.5$ and 0.25 $\mathrm{mm})$ and kept in $70 \%$ of alcohol for further studies. Dissected species were kept in lactophenol solution, while carapace and valves were retained in micropaleontological slides. Species found from 57 sites are listed in Appendix 2. Scanning electron microscope (SEM) photographs were taken at TÜBITAK-MAM (The Scientific and Technological Research Council of Turkey, Marmara Research Center, Turkey) (Appendices 3 and 4). Taxonomic classification and species identification were done following 

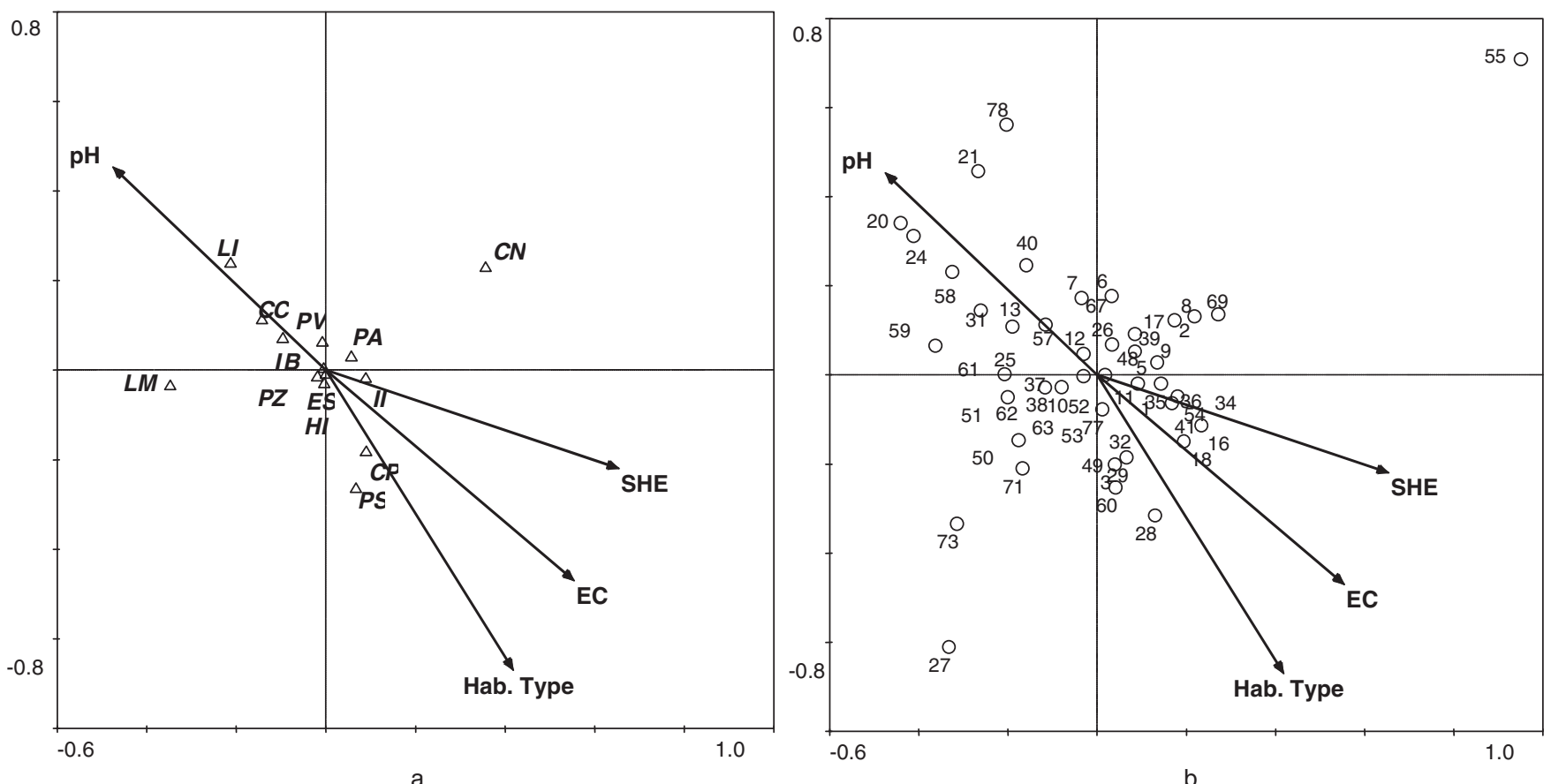

Fig. 2. CCA diagram shows four most affective environmental variables (arrows) on (a) 13 most abundant species from (b) 57 stations. Open circles $(\mathrm{O})$ and triangles show station numbers and species codes, respectively. Abbreviations are given in Table 1 and Appendix.

Meisch (2000). Specimens were housed at the Limnology Laboratory of the Department of Biology (Abant İzzet Baysal University) and are available upon request.

We used Canonical Correspondence Analysis (CCA) with Monte Carlo testing (499 permutations) to determine the relationship between environmental variables and the distribution of different ostracod species. As suggested in Ter Braak and Barendregt (1986), Ter Braak (1987) and Birks et al. (1990), the data used for CCA application were log-transformed and tested with detrended correspondence analyses (DCA). According to DCA, gradient lengths (5.041) were found higher than three, supporting suitability of the data for CCA application (Fig. 2). We used 13 species that occurred at least three times along with seven environmental variables (dissolved oxygen, water temperature, electrical conductivity, salinity, redox potential, $\mathrm{pH}$ and altitude) from 57 sites (Appendix 1). To categorize the habitats, we grouped them into five habitat types (A-E): A, Creek (creek, stream and river); B, Other (reed bed, water pit and slough); C, Lake (lake and dam lake); D, Spring; E, Pond (pond, pool and through), respectively. Therefore, binary data of the habitat types were used during the analyses. Linear regression (coefficient of correlation) for altitudinal relationship of different variables was analyzed using the analysis of variance (ANOVA) module in Excel. Spearman rank correlations were used to highlight relationships between species and environmental variables. Unweighted pair group mean averages (UPGMA) along with Jaccard's coefficient tests were used to evaluate possible clustering relationship among the species (Fig. 3). CCA outcomes were obtained from the CALIBRATE program, version 1.0 (Juggins, 2001), while UPGMA was done using MVSP version 3.1

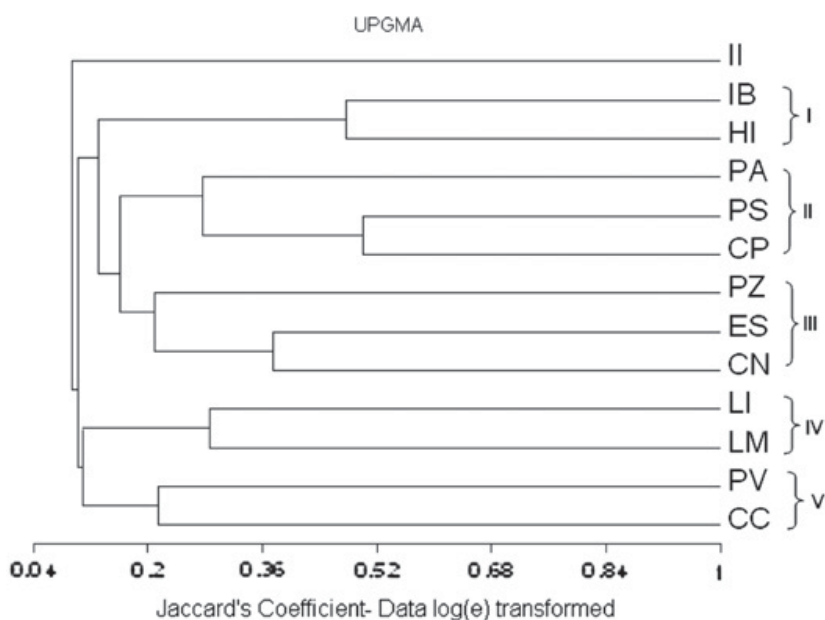

Fig. 3. UPGMA diagram shows five clustering groups (I-V) of 13 species. One species (II) shows an independent distribution. Abbreviations are given in Tables 1 and 3.

(Kovach, 1998). Species optimum estimates $\left(u_{k}\right)$ and ecological tolerance range $\left(t_{k}\right)$ were found using $\mathrm{C} 2$ program (Juggins, 2003). For all statistical analyses, we used only living adults, while juveniles, subfossils and broken valves and/or carapaces were not counted.

\section{Results}

We collected a total of 29 taxa (Fig. 4, Appendix 2) from 57 out of 78 water bodies (Fig. 2) at high altitudes (1659-2889 m a.s.1.) of Northeastern parts of Lake Van. 
Table 1. Number of species (Spe.) and numbers of stations (Sta.) for every $100 \mathrm{~m}$ a.s.l. of altitudinal range (Altitude, m a.s.1.) from 1650 to $2350 \mathrm{~m}$ a.s.1. No species were found at the range between 2050 and $2151 \mathrm{~m}$ a.s.1. Abbreviations include the most abundant 13 species in alphabetical order as: CC, Candona candida; CN, Candona neglecta; CP, Cypris pubera; ES, Eucypris sp.; HI, Heterocypris incongruens; IB, Ilyocypris bradyi; II, Ilyocypris inermis; LI, Limnocythere inopinata; LM, Leucocythere mirabilis; PA, Pseudocandona albicans; PS, Pseudocandona semicognita; PV, Potamocypris villosa; PZ, Prionocypris zenkeri.

\begin{tabular}{|c|c|c|c|c|c|c|c|c|c|c|c|c|c|c|c|}
\hline \multirow{2}{*}{$\begin{array}{l}\text { Altitude } \\
1650-1750\end{array}$} & \multirow{2}{*}{$\frac{\text { Spe. }}{26}$} & \multirow{2}{*}{$\begin{array}{c}\text { Sta. } \\
38\end{array}$} & \multicolumn{13}{|l|}{ Spe. } \\
\hline & & & $\overline{C C}$ & $\mathrm{CL}$ & $\mathrm{CN}$ & $\mathrm{CP}$ & $\mathrm{CV}$ & $\mathrm{DS}$ & ES & EV & $\mathrm{FF}$ & $\mathrm{HI}$ & $\mathrm{HS}$ & IB & $\overline{\mathrm{IG}}$ \\
\hline & & & II & LM & PA & PC & PK & PR & PS & PV & PZ & $\mathrm{SF}$ & $\mathrm{TL}$ & $\mathrm{TS}$ & \\
\hline $1751-1850$ & 5 & 6 & $\mathrm{HI}$ & IB & II & PV & $\mathrm{PZ}$ & & & & & & & & \\
\hline $1851-1950$ & 6 & 6 & $\mathrm{HI}$ & IB & II & LI & PV & $\mathrm{PZ}$ & & & & & & & \\
\hline $1951-2050$ & 1 & 1 & PV & & & & & & & & & & & & \\
\hline $2151-2250$ & 6 & 3 & $\mathrm{CC}$ & $\mathrm{CM}$ & $\mathrm{CN}$ & $\mathrm{HI}$ & $\mathrm{PO}$ & PV & & & & & & & \\
\hline $2251-2350$ & 7 & 3 & $\mathrm{CN}$ & ES & EV & $\mathrm{HI}$ & IB & PA & PF & & & & & & \\
\hline
\end{tabular}

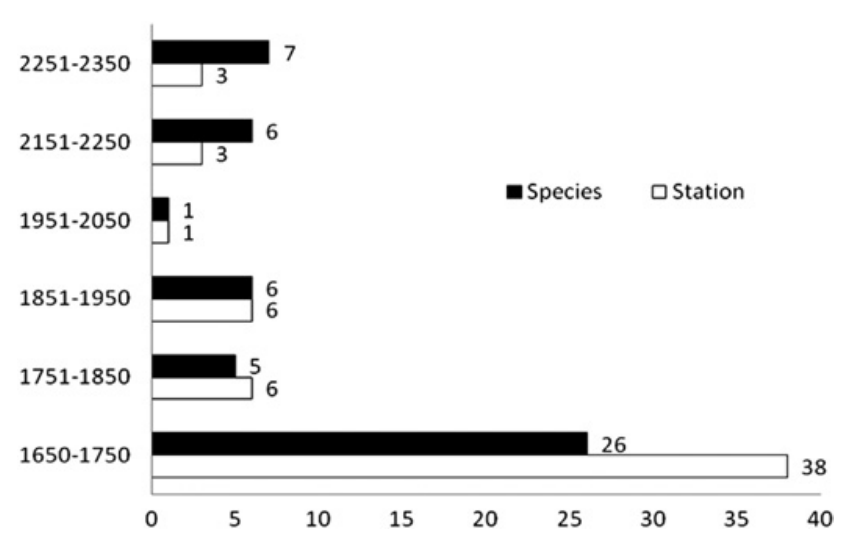

Fig. 4. Comparing the numbers of species and stations from the altitudinal ranges at each $100 \mathrm{~m}$ a.s.l. Note that there were no stations sampled between 2050 and $2150 \mathrm{~m}$ a.s.l. Accordingly, higher numbers of species (26 spp) were found from 1650 to $1750 \mathrm{~m}$ a.s.l. of ranges ( $X$-axis).

The largest number (26 species) of ostracods from 38 sampling sites was found between 1650 and $1750 \mathrm{~m}$ a.s.1. (Table 1). Above $1750 \mathrm{~m}$ a.s.l., the number of species present was not affected by altitude and/or numbers of stations sampled. Three species with cosmopolitan characteristics (Heterocypris incongruens (Ramdohr, 1808), Ilyocypris bradyi (Sars, 1890) and Potamocypris villosa (Jurine, 1820)) occurred most frequently between the altitudes of 1650-2350 m a.s.1. (Fig. 4). Except Limnocythere inopinata (Baird, 1843), no species showed a significant positive relationship with altitude $(P>0.05)$. However, the presence of $L$. inopinata was negatively correlated with altitude $(r=-0.894, P=0.05)$. H. incongruens revealed a significant correlation to habitat type, referring mostly to stagnant shallow water bodies. A positive correlation was found between two species (I. bradyi and Prionocypris zenkeri (Chyzer and Toth, 1858) ) and dissolved oxygen of water $(P=0.05)$. I. inermis and electrical conductivity were negatively correlated. Among the variables, four of them (redox potential $(F=2.331, P=0.012)$, station type $(F=2.63, P=0.012)$, $\mathrm{pH}(F=2.140, \quad P=0.032)$ and electrical conductivity $(F=1.991, P=0.032))$ showed significant effect on species composition (Fig. 2). The first axis of CCA ordination (Fig. 2) was able to explain about $68 \%$ of the relationship between 13 most abundant species and four environmental variables with a $41.5 \%$ of cumulative variance between species and environment relation (Table 2).

Regression analyses suggested that altitude was not correlated with species distribution or environmental variables. For example, correlation between conductivity and altitude was not significant (ANOVA: $P=0.07$, $\left.r^{2}=0.04, \mathrm{Adj}-r^{2}=0.027\right)$ since the data used in this study can only explain about 0.027 (or $c a .3 \%$ ) the relationship between altitude and conductivity. UPGMA dendrogram displayed five clustering groups (Fig. 3). Groups (I-V) include two ( $H$. incongruens and $I$. bradyi,), three (P. semicognita, Pseudocandona albicans and Cypris pubera), three (C. neglecta, P. zenkeri and Eucypris sp.), two (L. inopinata and Leucocythere mirabilis) and two species ( $P$. villosa and Candona candida), respectively. Species in each group seems to have some common ecological (and biological) characteristics (Table 3 , also see below).

\section{Discussion and conclusion}

Altitude has been discussed as a key habitat factor limiting the distribution of ostracods (e.g., Mezquita et al., 1999). Much of this effect of altitude on species distributions has been attributed to the indirect effects that altitude has via its influences on other habitat characteristics. For example, in the lakes of Patagonia (southern South America), Rogora et al. (2008) demonstrated negative correlations between conductivity and altitude between 679 and $1466 \mathrm{~m}$ a.s.l., suggesting lower conductivities (referring to low salinity) in waters are coupled with increasing altitude. Consistent with this rationale, Reeves et al. (2007) found that altitude affected water depth, water chemistry, temperature and conductivity, and that as a result groundwater ostracods were restricted to midaltitude locations in the Pilbara region of northwestern Australia. Similarly, Külköylüoğlu et al. (2011) provided evidence that increasing altitude was closely correlated to lower conductivities among 90 different aquatic habitats (530-1095 m a.s.1.) in the Diyarbakır region of Turkey. In contrast, during the present study, we found no significant association of altitude to conductivity (Fig. 2), or to any of the other ecological variables measured. Indeed, in this 
Table 2. Summary of CCA results. Accordingly, about $68 \%$ of the correlation between species and environment can be explained by the first axis. $r^{2}=0.15$. Unexplained variation $=4.301$.

\begin{tabular}{|c|c|c|c|c|c|}
\hline Axes & 1 & 2 & 3 & 4 & Total interia \\
\hline Eigenvalues & 0.318 & 0.248 & 0.141 & 0.059 & 5.067 \\
\hline Species-environment correlations & 0.679 & 0.657 & 0.528 & 0.370 & \\
\hline \multicolumn{6}{|l|}{ Cumulative percentage variance } \\
\hline Species data & 6.3 & 11.2 & 14.0 & 15.1 & \\
\hline Species-environment relation & 41.5 & 73.9 & 92.3 & 100.0 & \\
\hline Sum of all eigenvalues & & & & & 5.067 \\
\hline Sum of all canonical eigenvalues & & & & & 0.766 \\
\hline
\end{tabular}

Table 3. Species optima estimates $\left(u_{k}\right)$ and tolerance values $\left(t_{k}\right)$ of 13 most abundant species (Spe.) with seven ecological variables. Group no. represents clustering groups in UPGMA. $\mathrm{N}_{2}$ implies Hill's coefficient value (measure of effective number of occurrences) while Count and Max represent numbers of species occurrences and maximum numbers of individuals, respectively. Abbreviations: CC: Candona candida; CN, Candona neglecta; CP, Cypris pubera; ES, Eucypris sp.; HI, Heterocypris incongruens; IB, Ilyocypris bradyi; II, Ilyocypris inermis; LI, Limnocythere inopinata; LM, Leucocythere mirabilis; PA, Pseudocandona albicans; PS, Pseudocandona semicognita; PV, Potamocypris villosa; PZ, Prionocypris zenkeri. SHE (redox potential, mV), Hatyp (habitat type), DO (dissolved oxygen, mg. $\mathrm{L}^{-1}$ ), EC (electrical conductivity, $\left.25{ }^{\circ} \mathrm{C}\right), T^{\circ} \mathrm{C}(\mathrm{w})$ (water temperature). *Indicates a single species as independent group.

\begin{tabular}{|c|c|c|c|c|c|c|c|c|c|c|c|c|c|c|c|c|c|c|}
\hline \multirow{2}{*}{$\begin{array}{l}\text { Groups in } \\
\text { UPGMA }\end{array}$} & \multirow[b]{2}{*}{ Spe. } & \multirow[b]{2}{*}{ Count } & \multirow[b]{2}{*}{ Max. } & \multirow[b]{2}{*}{$\mathrm{N}_{2}$} & \multicolumn{2}{|c|}{$\mathrm{pH}$} & \multicolumn{2}{|c|}{ SHE } & \multicolumn{2}{|c|}{ Hatyp } & \multicolumn{2}{|c|}{$\overline{\mathrm{DO}}$} & \multicolumn{2}{|c|}{$\mathrm{EC}$} & \multicolumn{2}{|c|}{$T{ }^{\circ} \mathrm{C}(\mathrm{w})$} & \multicolumn{2}{|c|}{ Altitude (m a.s.l.) } \\
\hline & & & & & $\overline{u_{k}}$ & $t_{k}$ & $u_{k}$ & $\overline{t_{k}}$ & $\overline{u_{k}}$ & $\overline{t_{k}}$ & $\overline{u_{k}}$ & $\overline{t_{k}}$ & $\overline{u_{k}}$ & $\overline{t_{k}}$ & $\overline{u_{k}}$ & $t_{k}$ & $\overline{u_{k}}$ & $\overline{t_{k}}$ \\
\hline \multirow[t]{3}{*}{1} & $\mathrm{II}^{*}$ & 6 & 25 & 2.08 & 8.53 & 0.24 & 98.24 & 16.24 & 3.10 & 0.77 & 6.11 & 1.42 & 634.7 & 46.65 & 21.76 & 1.77 & 1743.6 & 68.17 \\
\hline & IB & 30 & 300 & 4.19 & 8.59 & 0.41 & 91.79 & 24.60 & 3.99 & 1.36 & 6.79 & 5.21 & 562.0 & 175.7 & 23.45 & 3.68 & 1742.9 & 109.5 \\
\hline & HI & 30 & 300 & 5.14 & 8.36 & 0.46 & 105.4 & 29.97 & 4.09 & 1.23 & 5.57 & 1.50 & 547.2 & 179.9 & 22.95 & 5.16 & 1762.9 & 172.1 \\
\hline \multirow[t]{3}{*}{2} & PA & 4 & 3 & 3.57 & 8.41 & 0.21 & 107.6 & 10.12 & 2.90 & 1.62 & 5.56 & 1.28 & 574.6 & 134.9 & 20.11 & 3.61 & 1891.8 & 308.1 \\
\hline & PS & 3 & 36 & 2.49 & 8.29 & 0.21 & 104.5 & 11.44 & 5.00 & 1.32 & 3.17 & 1.65 & 686.1 & 122.3 & 27.65 & 1.38 & 1689.3 & 30.94 \\
\hline & $\mathrm{CP}$ & 4 & 5 & 3.81 & 8.36 & 0.19 & 104.2 & 5.40 & 4.6 & 0.93 & 3.52 & 1.16 & 678.6 & 112.4 & 26.61 & 4.54 & 1681.4 & 20.83 \\
\hline \multirow[t]{3}{*}{3} & PZ & 8 & 5 & 5.89 & 8.31 & 0.59 & 108.4 & 31.38 & 2.52 & 1.36 & 7.75 & 5.38 & 593.2 & 156.2 & 22.12 & 2.68 & 1729.2 & 92.61 \\
\hline & ES & 4 & 16 & 3.19 & 8.40 & 0.32 & 105.6 & 18.33 & 2.95 & 1.79 & 5.92 & 1.15 & 501.0 & 160.3 & 21.77 & 2.44 & 2055.9 & 333.8 \\
\hline & $\mathrm{CN}$ & 5 & 12 & 2.84 & 8.23 & 0.30 & 152.4 & 50.09 & 3.63 & 1.42 & 5.67 & 0.98 & 569.2 & 82.24 & 14.92 & 8.21 & 2043.9 & 328.0 \\
\hline \multirow[t]{2}{*}{4} & LI & 5 & 6 & 4.56 & 9.48 & 0.82 & 43.47 & 47.45 & 1.63 & 1.05 & 4.88 & 1.93 & 230.8 & 336.7 & 21.85 & 4.57 & 1705.4 & 98.20 \\
\hline & LM & 3 & 17 & 2.44 & 8.61 & 1.30 & 74.89 & 52.20 & 2.94 & 2.60 & 6.25 & 0.31 & 307.1 & 367.6 & 23.32 & 0.19 & 1662.2 & 0.855 \\
\hline \multirow[t]{2}{*}{5} & PV & 11 & 4 & 9.22 & 8.35 & 0.43 & 109.0 & 26.21 & 2.51 & 0.78 & 5.63 & 1.68 & 504.3 & 207.9 & 20.55 & 4.55 & 1805.6 & 147.4 \\
\hline & $\mathrm{CC}$ & 4 & 3 & 3.90 & 8.83 & 0.53 & 78.12 & 33.39 & 2.27 & 1.00 & 6.29 & 1.08 & 485.3 & 174.3 & 22.9 & 0.70 & 1824.0 & 268.6 \\
\hline
\end{tabular}

study, altitude could only explain about $3 \%$ of the variation present in conductivity.

Responses to altitude and requirements of individual species may be species-specific characteristics. For example, we found, L. inopinata with the highest tolerance (0.82) and optimum values for $\mathrm{pH}$ of 9.48 (Table 3 ). The presence of this species was negatively correlated with altitude $(r=-0.894, P=0.05)$ and restricted to $1661-$ $1905 \mathrm{~m}$ a.s.1. This species has previously been found in a variety of habitats and its high tolerances to salinity and temperature variation previously described (Cohen et al., 1983; Mischke, 2001; Külköylüoğlu et al., 2011). Similarly, Yılmaz and Külköylüoğlu (2006) reported that L. inopinata had the highest optimum and tolerances to dissolved oxygen and temperature in a small reservoir at about $1400 \mathrm{~m}$ a.s.1. in Bolu (Turkey). Both the fossil and living forms of the species were also recovered from brackish waters at about zero altitudes (Lake Arendsee, Germany, ca. $23 \mathrm{~m}$ ) (Scharf, 1998) and (Lake Büyükçekmece, Turkey, ca. $1 \mathrm{~m}$.) (Külköylüoğlu et al., 1995). In the waters of China (Lake Luanhaizi, Lake Qinghai), and nearby aquatic habitats $L$. inopinata was also found at about 3200 and $3450 \mathrm{~m}$ a.s.1., (Mischke et al., 2003; Li et al., 2010, respectively). The subfossil and recent forms of $L$. inopinata were one of the most abundant in relatively saline (4.62-14.74 g. $\mathrm{L}^{-1}$ ) waters of Lake Qinghai (Li et al., 2010). The combination of results from these previous studies together with the results presented here make it clear that distribution of L. inopinata is probably much more extensive than previously recognized.

The first group clustered together based on UPGMA (Fig. 3) included the two cosmopolitan species (I. bradyi and $H$. incongruens), both of which have large environmental tolerances (Sarı and Külköylüoğlu, 2010). During the present study, these two species were the most common species at most altitudinal ranges (1659-2312 $\mathrm{m}$ a.s.1.). This is probably the highest ranges for both species found (Table 1). The prevalence of these two species co-occurring is not surprising for at least two reasons: first, both species were found closer to the center of CCA diagram (Fig. 2) and second, they showed relatively high tolerance and optimum values for station (habitat) type (Table 3). Further, most recent studies (e.g., see Mischke et al., 2003; Li et al., 2010) showed that both species can be 
found at altitudes over $3000 \mathrm{~m}$ a.s.l. in Chinese waters. Results support the idea that cosmopolitan species - like these two - with high tolerances appears to have high dispersal ability and survival chances in variety of habitats. Since cosmopolitans seem to be more tolerant than non-cosmopolitans, their numbers will tend to increase with decreasing water quality. These data support the "pseudorichness hypothesis" (Külköylüoğlu, 2004; Dügel et al., 2008), which predicts an increase in cosmopolitan species with decreasing water quality. Accordingly, species richness of habitats should account quality of species as much as quantity.

The second UPGMA cluster consists of three species (Pseudocandona semicognita (Schäfer, 1934), P. albicans (Schäfer, 1934) and C. pubera O.F. Müller, 1776). $P$. semicognita was recently reported in a relatively cold creek (ca. $1273 \mathrm{~m}$ a.s.1.) with alkaline waters and low salinity in Bolu region, Turkey (Sarı and Külköylüoğlu, 2010; Külköylüoğlu, unpublished data). In this study, we found $P$. semicognita in warm $\left(c a .25-28.5^{\circ} \mathrm{C}\right)$, alkaline (pH 8.18-8.59) and brackish type of waters (conductivity $\left.624-868 \mu \mathrm{S} . \mathrm{cm}^{-1}\right)$ with low dissolved oxygen $(2.45-5.44$ mg. $\mathrm{L}^{-1}$ ) values (Fig. 2, Appendix 1). In contrast, a few earlier studies reported the species in shallow acidic $(\mathrm{pH}$ 5.5-6) waters (Scharf, 1982; Meisch, 2000). Since we do not have enough information about the ecology and distribution (Meisch, 2000) of P. semicognita, such results about their ecological characteristics cannot be generalized at the moment. Unlike $P$. semicognita, we have better information on the other two species $(P$. albicans and C. pubera). C. pubera has a broader geographical distribution than $P$. albicans in Turkey (Schäfer, 1952; Gülen et al., 1996). Some recent observations in Turkey revealed that $C$. pubera was able to survive in a highly alkaline $(\mathrm{pH}$ 9.3), warm (temperature ca. $30.3{ }^{\circ} \mathrm{C}$ ) and relatively well oxygenated (DO $12.39 \mathrm{mg} . \mathrm{L}^{-1}$ ) shallow ephemeral pond located at about $1350 \mathrm{~m}$ a.s.l. (Külköylüoğlu, unpublished data). Similarly, the species was also found in a man-made lake in Bolu (Turkey) where water $\mathrm{pH}$ (8.23), oxygen (8.96 mg. $\left.\mathrm{L}^{-1}\right)$, and temperature $\left(21.9^{\circ} \mathrm{C}\right)$ were measured at about $1340 \mathrm{~m}$ a.s.l. (Külköylüoğlu, 2004). Most recently, Li et al. (2010) reported C. pubera in a man-made pond located near Lake Qinghai (China) at about 3200 m. a.s.1. The authors found the species in a pond with a salinity of about 0.49 g.L $\mathrm{L}^{-1}$. These results suggest that $C$. pubera has a wide tolerance levels to several environmental variables, preferring warm and alkaline habitats from low to high altitudes. During this study, these three species were among the rarest occurring species in some ecological conditions (Fig. 2(a, b)). For example, they all have low to medium optimum and tolerance levels to altitude. When $P$. semicognita and C. pubera were found at 1650 and 1750 $\mathrm{m}$ a.s.1. (Fig. 4), they showed the highest optimum values for water temperature and electrical conductivity but lowest for dissolved oxygen (Table 3 ). Unlike $P$. semicognita and $C$. pubera, $P$. albicans had an extensive altitudinal range; the species was present from 1650 to $2350 \mathrm{~m}$ a.s.1. Unfortunately little is known about the ecology and distribution of $P$. albicans, with information limited to only a few reports in Turkey. Mezquita et al. (1996) also found the species in a Spanish river with highly alkaline (pH 8.44), saline (conductivity $542.8 \mu \mathrm{g} . \mathrm{L}^{-1}$ ), warm (water temperature $18.4{ }^{\circ} \mathrm{C}$ ) and moderately oxygenated (DO $7.9 \mathrm{mg.L^{-1 }}$ ) waters. More recently, Külköylüoğlu et al. (2010) found P. albicans in a natural lake (Lake Sünnet, Bolu, Turkey) within a narrow temperature $\left(17.60-14.14^{\circ} \mathrm{C}\right)$ and a $\mathrm{pH}(7.45-7.85)$ range. In Lake Sünnet, the species also displayed the highest optimal (7.49) and tolerances (2.99) for dissolved oxygen. Based on the data available, the species appears to be mesohalophilic (Meisch, 2000), mesothermophilic and titanoeuryplastic (Hartmann and Hiller, 1977). However, finding this species closer to the center of CCA diagram (Fig. 2(a)) may be the signal that species tolerances and preferences can be much higher than previously known.

The third cluster of UPGMA dendrogram (Fig. 3) encompasses three species (Candona neglecta Sars, 1887, P. zenkeri and Eucypris sp.). Of these three, P. zenkeri was common at altitudes between 1650 and $1950 \mathrm{~m}$ a.s.l., while C. neglecta was found in broader ranges $(1650-2350 \mathrm{~m}$ a.s.1., excluding 1751-2051 m a.s.1.). Interestingly, C. neglecta was not found at all elevations, but had the highest tolerance for altitude. Both species showed relatively high optimum and tolerance levels to $\mathrm{pH}$ and redox potential (Table 3 ). $P$. zenkeri displayed the highest optimal $\left(u_{k}=7.75\right)$ and tolerance $\left(t_{k}=5.38\right)$ levels to dissolved oxygen, while $C$. neglecta had the highest tolerance $\left(t_{k}=8.21\right)$ and lowest optimal $\left(u_{k}=14.9\right)$ temperature. Also, C. neglecta showed the lowest tolerance to electrical conductivity $\left(t_{k}=82.24\right)$. Both species are commonly known from the aquatic habitats of Turkey and most European countries, as well as N. America and Asia. Candona neglecta was reported in organically rich polluted waters tolerating low levels of oxygen below and around (3 mg. ${ }^{-1}$ ) (Meisch, 2000; Külköylüoğlu, 2003, 2005). C. neglecta had low tolerance to cold water temperature in limnocrene spring located at about $1400 \mathrm{~m}$ a.s.1. in Bolu, Turkey (Külköylüoğlu and Yılmaz, 2006). In a long-term study on a natural lake (Lake Abant, Turkey) located at about $1345 \mathrm{~m}$ a.s.l., Dügel et al. (2008) found no significant correlation between environmental variables and C. neglecta occurrence. C. neglecta actually showed the highest optimum (17.97) and relatively high tolerance (5.879) values for water temperature variation. In China, C. neglecta was also reported from alkaline $(\mathrm{pH} 8.5-8.7)$ and saline $\left(0.92-12.30\right.$ g. $\left.\mathrm{L}^{-1}\right)$ waters at about $3200 \mathrm{~m}$ a.s.1. (Li et al., 2010). These results are comparable and overall support the idea that $C$. neglecta has wide ranges of tolerances to different variables showing typical characteristics of cosmopolitan species. According to Table 1, $P$. zenkeri seems to have higher tolerance to salty waters than $C$. neglecta. Indeed, the species was common from two rheocrene springs with laminar flow where it had higher tolerance (80.24) to electrical conductivity (272.9$708 \mu \mathrm{S} . \mathrm{cm}^{-1}$ ) than C. neglecta (64.10) (Karakaş-Sarı and Külköylüoğlu, 2008). Overall, these results support high tolerances for this species and this may explain wide ranges of geographical distribution at high altitudes. 
Based on UPGMA, L. inopinata and L. mirabilis Kaufmann, 1892 were also grouped together. Relatively good data are available for $L$. inopinata (see above discussion), but little is known about the ecology of L. mirabilis which seems to be tolerant to salinity changes up to 3\%o (Stephanides, 1948; Savolainen and Valtonen, 1983). Living and fossil individuals of L. mirabilis have been reported from the cold waters of the lakes Attersee and Mondsee located at about $480 \mathrm{~m}$ a.s.1. in Upper Austria (Danielopol et al., 1989). Based on these reports, L. mirabilis appears to be sensitive to water quality changes (e.g., reduction in oxygen and temperature) and thus useful as an indicator of habitat variation resulting from natural (Scharf, 1993) and/or cultural eutrophication in alpine lakes (Danielopol et al., 1989). However, elsewhere, L. mirabilis was found in high alkaline ( $\mathrm{pH} 8.4)$, cool $\left(15^{\circ} \mathrm{C}\right)$ and medium oxygenated (DO $\left.8.8 \mathrm{mg} . \mathrm{L}^{-1}\right)$ shallow $(10-30 \mathrm{~cm})$ waters of a temporary lake, Lake Musalar (Konya, Turkey) at about $925 \mathrm{~m}$ (Altınsaçlı and Griffiths, 2001). Most recently the living forms of $L$. mirabilis were found in freshwaters of a stream site in Thrace region in Turkey (Özuluğ and Yaltalıer, 2008). During the present study, L. mirabilis was reported three times, two of which were Lake Van, which is the largest saline inland water of Turkey. The third site was a small lagoon connected to Lake Van at about $1663 \mathrm{~m}$ a.s.1. The species was found within relatively high alkaline lake waters ( $\mathrm{pH}$ 7.59-9.69) (see Appendix 1). Thus in this study, L. mirabilis showed the highest tolerance values for electrical conductivity, temperature, $\mathrm{pH}$, redox potential and station type (Table 3). The contrasts among previous reports and the results presented here suggest that the ecological characteristics of L. mirabilis are probably much broader than previously thought and require further investigation prior to use as an indicator of water quality.

The last group clustered based on UPGMA analysis (Fig. 3) consisted of two species: $P$. villosa and $C$. candida (O.F. Müller, 1776). Both species are widely distributed and may be considered cosmopolitan (Külköylüoğlu, 2004). C. candida has been found in highly varied lentic and lotic habitats. Graf (1938, in Meisch, 2000) reported the species from the Alps up to $2500 \mathrm{~m}$ a.s.1. More recently C. candida was also found in Lake Qinghai (China) at about $3200 \mathrm{~m}$ a.s.l. of altitude where water was slightly acidic ( $\mathrm{pH} 6.1-6.6$ ), within the salinity ranges of $0.32-$ 0.59 g. $\mathrm{L}^{-1}$ (Li et al., 2010). Although these authors suggested that $C$. candida was typically found in cold waters, the species can apparently tolerate different types of environmental variables including water temperature (Delorme, 1991; Külköylüoğlu and Vinyard, 2000; Külköylüoğlu et al., 2007). For example, C. candida tolerates acidic to highly alkaline ( $\mathrm{pH}$ 5.4-13), warm (up to $30^{\circ} \mathrm{C}$ ) and well oxygenated waters in Canada (Delorme, 1991). In the present study, we found $C$. candida in high alkaline waters of small creeks, ponds $(\mathrm{pH} 8.49-8.64)$ and Lake Van ( $\mathrm{pH}$ 9.59). This suggests that C. candida is highly tolerant to variable water conditions.

Unlike C. candida, P. villosa is not common in Turkey. Previously, Roca and Baltanás (1993) and Mezquita et al.
(1999) suggested $P$. villosa as a cold stenothermal species at higher altitudes ( $>600 \mathrm{~m}$ a.s.l.). Some of the previous studies, however, reported the species in springs, springrelated waters, littoral zones of lakes and ponds located at lower to higher altitudinal ranges (Meisch, 2000; Rossetti et al., 2006). Similarly, Külköylüoğlu and Yılmaz (2006) reported that $P$. villosa had the highest optimal conductivity and salinity among a suite of species in a helocrene spring in Bolu, Turkey located at about $1400 \mathrm{~m}$ a.s.1., implying a wide range of tolerance. $P$. villosa is reportedly more prevalent in shallow stagnant waters where it shows high tolerance to eutrophication (Meisch, 2000). Li et al. (2010) reported that the shells of this species were highly abundant in a spring with slightly acidic conditions ( $\mathrm{pH}$ 6.6) and salinity of 0.57 g. $\mathrm{L}^{-1}$ at about $3200 \mathrm{~m}$ a.s.1. In this study, we found $C$. candida to be present but not abundant from 1650 to $2250 \mathrm{~m}$ a.s.l. Between these altitudes the species occurred in a wide range of temperatures (11$\left.25.7^{\circ} \mathrm{C}\right)$, electrical conductivity $\left(122-740 \mu \mathrm{S} . \mathrm{cm}^{-1}\right), \mathrm{pH}$ (7.27-8.93) and oxygen (DO 3.56-7.65 mg.. ${ }^{-1}$ ). We did not find any strong evidence for the affect of a particular environmental variable on this species distribution. C. candida appears to have the widest distribution under a variety of environmental conditions.

Finally, our results suggest that several (if not all) species in this study are highly tolerant to environmental variability. However, the levels and the type(s) of such variables differ from species to species. Knowledge on species-specific characteristics can help increase our understanding of the natural history of ostracods and their importance in ecological, biological and evolutionary studies. Depending upon species specific characteristics ostracods may be useful in the reconstruction of historical conditions based on their fossil distribution. The majority of the species discussed here are bottom-dwelling ostracods with reduced or absent swimming ability. This may indicate that rather than active dispersal, passive dispersal via predators or incidental transmission more likely explains their distribution among water bodies. Also, seasonality can be responsible for species occurrence. However, our sampling period does not cover all seasons. Therefore, additional samples should be collected in different seasons in order to generalize the conclusions drawn in this study.

Acknowledgements. We acknowledge Dr Ned Dochtermann and Dr Mary M. Peacock (University of Nevada, Reno, U.S.A.) for their invaluable comments and suggestions on the manuscript. We also thank Ceren Altınbağ (Abant İzzet Baysal University, Bolu, Turkey) for her help during laboratory work.

\section{References}

Altınsaçlı S. and Griffiths H.I., 2001. The freshwater ostracods Hungarocypris and Leucocythere from Turkey. Crustaceana, 74, 681-688.

Birks H.J.B., Line J.M., Juggins S., Stevenson A.C. and Ter Braak C.J.F., 1990. Diatoms and $\mathrm{pH}$ reconstruction. Phil. Trans. R. Soc., 327, 263-278. 
Cohen A.S., Dussinger R. and Richardson J., 1983. Lacustrine paleochemical interpretations based on Eastern and Southern African Ostracodes. Palaeogeogr. Palaeoclim. Palaeoecol., 43, 129-152.

Danielopol D.L., Martens K. and Casale L.M., 1989. Revision of the genus Leucocythere Kaufmann, 1892 (Crustacea, Limnocytheridae), with the description of a new species and two new tribes. Biologie, 59, 63-94.

Delorme L.D., 1991. Ostracoda. In: Thorpe J.H. and Covich A.P. (eds.), Ecology and Classification of North American Invertebrates, Academic Press Inc., California, 691-722.

Dügel M., Külköylüoğlu O. and Kılıç M., 2008. Species assemblages and habitat preferences of ostracoda (Crus-tacea) in Lake Abant (Bolu, Turkey). Belg. J. Zool. 138, 50-59.

Forester R.M. and Brouwers E.M., 1985. Hydrochemical parameters governing the occurrence of estuarine and marginal estuarine ostracodes: an example from SouthCentral Alaska. J. Paleontol., 59, 344-369.

Graf H., 1938. Beitrag zur Kenntnis der Muschelkrebse des Ostalpengebietes. Arch. Hydrobiol., 33, 401-502.

Gülen D., Özuluğ O.A. and Bilgin F.H., 1996. Ostracoda (Crustacea) fauna of Kabaklı Spring (Diyarbakır). In: XIII. Ulusal Biyoloji Kongresi, İstanbul, (Abstract in English), $162-172$.

Hartmann G. and Hiller D., 1977. Beitrag zur kenntnis der ostracodenfauna des harzes und seines nördlichen vorlandes (unter besonderer Berücksichtigung des Männchens von Candona candida), 125 Jahre Naturwiss. Verein Goslar, 99-116.

Jersabeck C.D., Brancelj A., Stoch F. and Schabetsberger R., 2001. Distribution and ecology of copepods in mountain of the Eastern Alps. Hydrobiologia, 453/454, 309-324.

Juggins S., 2001. CALIBRATE Version 1.0. A C ++ Program for Analyzing and Visualizing Species Environment Relationships and for Predicting Environment Values from Species Assemblages, User Guide Version 1.0. Department of Geography, University of Newcastle, UK.

Juggins S., 2003. C2 User Guide. Software for Ecological and Palaeoecological Data Analysis and Visualization, University of Newcastle, Newcastle upon Tyne, UK, 69 p.

Karakaş-Sarı P. and Külköylüoğlu O., 2008. Comparative ecology of Ostracoda (Crustacea) in two rheocrene springs (Bolu, Turkey). Ecol. Res., 23, 821-830.

Kovach W., 1998. Multi-Variate Statistical Package, version 3.0, Kovach Computer Services, Pentraeth, UK.

Külköylüoğlu O., 2003. Ecology of Freshwater Ostracoda (Crustacea) from Lakes and Reservoirs in Bolu, Turkey. J. Freshwat. Ecol., 18, 343-347.

Külköylüoğlu O., 2004. On the use of Ostracods (Crustacea) as bioindicator species in different aquatic habitats in the Bolu region, Turkey. Ecol. Indicators, 4, 139-147.

Külköylüoğlu O., 2005. Factors effecting Ostracoda (Crustacea) occurrence in Yumrukaya Reedbeds (Bolu, Turkey). Wetlands, 25, 224-227.

Külköylüoğlu O. and Yılmaz F., 2006. Ecological requirements of Ostracoda (Crustacea) in three types of springs in Turkey. Limnologica, 36, 172-180.

Külköylüoğlu O., Altınsaçlı S., Kılıç M. and Kubanç C., 1995. The Ostracoda (Crustacea) Fauna of Lake Büyükçekmece (İstanbul) and seasonal distributions. Turk. J. Zool., 19, 249-256.

Külköylüoğlu O. and Vinyard G.L., 2000. Distribution and ecology of freshwater Ostracoda (Crustacea) collected from springs of Nevada, Idaho, and Oregon: a preliminary study. West. N. Am. Naturalist, 60, 291-303.

Külköylüoğlu O., Meisch C. and Rust W.R., 2003. A new genus (Thermopsis thermophila n. gen.) of Ostracoda (Crustacea) from hot springs of western North America. Hydrobiologia, 499, 113-123.

Külköylüoğlu O., Dügel M. and Kılıç M., 2007. Ecological requirements of Ostracoda (Crustacea) in a heavily polluted shallow lake, Lake Yeniçağa (Bolu, Turkey). Hydrobiologia, $585,119-133$.

Külköylüoğlu O., Dügel M., Balcı M., Deveci A., Avuka D. and Kılıç M., 2010. Limnoecological relationships between water-level-fluctuations and Ostracoda (Crustacea) species composition in Lake Sünnet (Bolu, Turkey). Turk. J. Zool., 34, 429-442.

Külköylüoğlu, O., Akdemir D. and Yüce R., 2011. Ecological tolerance and optimum levels of freshwater Ostracoda (Crustacea) from high altitudes (Diyarbakır, Turkey). Limnology, DOI 10.1007/s10201-011-0357-1.

Laprida C., Díaz A., and Ratto N., 2006. Ostracods (Crustacea) from thermal waters, southern Altiplano, Argentina. Micropaleontology, 52, 177-188.

Lawton J.H., MacGarwin M. and Heads P.A., 1987. Effects of altitude on the abundance of species richness of insect herbivores on Bracken. J. Anim. Ecol., 56, 147-160.

Li X., Liu W., Zhang L. and Sun Z., 2010. Distribution of recent ostracod species in the Lake Qinghai area in northwestern China and its ecological significance. Ecol. Indicators, 10, 880-890.

Meisch C., 2000. Freshwater Ostracoda of Western and Central Europe, Suesswasserfauna von Mitteleuropa 8/3, Spektrum Akademischer Verlag, Heidelberg, Berlin, 522 p.

Mezquita F., Sanz-Brau A., and Miracle M.R., 1996. New data on freshwater ostracod assemblages (Crus- tacea, Ostracoda) from Cuenca (Central Spain). Bull. Soc. Nat. Luxemb., 97, 239-247.

Mezquita F., Tapia G. and Roca J.R., 1999. Ostracoda from springs on the eastern Iberian Peninsula: ecology, biogeography and palaeolimnological implications. Paleogeogr. Paleoclim. Palaeoecol., 148, 65-85.

Mischke S., 2001. Mid and Late Holocene palaeoenvironment of the lakes Eastern Juyanze and Sogo Nur in NW China, based on ostracod species assemblages and shell chemistry. Berl. Geowiss. Abh., Reihe E., 35, 131 p.

Mischke S., Herzschuh U., Kürschner H., Fuchs D., Chen F.H., Meng F. and Sun Z.C., 2003. Sub-recent Ostracoda from Qilian Mountains (NW China) and their ecological significance. Limnologica, 33, 280-292.

Özuluğ O.A. and Yaltalıer S., 2008. Ostracoda species collected from the Rezve stream (Thrace, Turkey). IUFS J. Biol., 67, 93-96.

Pounds J.A., Bustamente M.R., Coloma L.A., Consuegra J.A. and Fogden M.P.L., 2006. Widespread amphibian extinctions from epidemic disease driven by global warming. Nature, 439, 161-167.

Reeves J.M., De Deckker P. and Halse S.A., 2007. Groundwater ostracods from the arid Pilbara region of northwestern Australia: distribution and water chemistry. Hydrobiologia, 585, 99-118.

Roca J.R. and Baltanás A., 1993. Ecology and distribution of Ostracoda in Phyrenean springs. J. Crust. Biol., 13, 165-174. 
Rogora M., Massaferro J., Marchetto A., Tartari G. and Morsello R., 2008. The water chemistry of some shallow lakes in Northern Patagonia and their nitrogen status in comparison with remote lakes in different regions of the globe. J. Limnol., 67, 75-86.

Rossetti G., Martens K., Meisch C., Tavernelli S. and Pieri V., 2006. Small is beautiful: diversity of freshwater ostracods (Crustacea, Ostracoda) in marginal habitats of the province of Parma (Northern Italy). J. Limnol. 65, 121-131.

Sarı N. and Külköylüoğlu O., 2010. Ostracods (Crustacea) and habitat similarities in the Bolu region (Turkey). Turk. J. Zool., 34, 225-230.

Savolainen I. and Valtonen T., 1983. Ostracods of the northeastern Bothnian Bay and population dynamics of the principal species. Aquilo, Ser. Zool., 22, 69-76.

Schäfer H.W., 1952. Über Süswasser-Ostracoden aus der Türkei. İstanbul Üniversitesi Fen Fakültesi Araştırma Enstitüsü Yayınları, Hidrobiologi, Seri B. 1(1), 7-32.

Scharf B.W., 1982. Muschelkrebse aus dem Murnauer Moos (Crustacea, Ostracoda). Entomofauna, Suppl. 1, 119-123.

Scharf B.W., 1993. Ostracoda (Crustacea) from eutrophic and oligotrophic maar lakes of the Eifel (Germany) in the Late and Post Glacial. In: McKenzie K.G. and Jones P.J. (eds.),
Ostracoda in the Earth and Life Sciences, A.A. Balkema, Rotterdam, Brookfield, 453-464.

Scharf B.W., 1998. Eutrophication history of Lake Arendsee (Germany). Paleogeogr. Paleoclim. Paleoecol., 140, 85-96.

Stephanides T., 1948. A Survey of the fresh-water biology of Corfu and of certain other regions of Greece. Prak. Hellenic Hydrobiol. Inst., 2, 1-263.

Ter Braak C.J.F., 1987. The analysis of vegetation-environment relationships by canonical correspondence analysis. Vegetatio, 69, 69-77.

Ter Braak C.J.F. and Barendregt J.G., 1986. Weighted averaging of species indicator values: its efficiency in environmental calibration. Math. Biosci., 78, 57-72.

Tolotti M., Manca M., Angeli N., Morabito G., Thaler B., Rott E. and Stuchlik E., 2006. Phytoplankton and zooplankton associations in a set of Alpine high altitude lakes: geographic distribution and ecology. Hydrobiologia, 562, 99-122.

Vyverman W., 1992. Altitudinal distribution of non-cosmopolitan desmids and diatoms in Papua New Guinea. Eur. J. Phycol., 27, 49-63.

Yılmaz F. and Külköylüoğlu O., 2006. Tolerance, optimum ranges, and ecological requirements of freshwater Ostracoda (Crustacea) in Lake Aladağ (Bolu, Turkey). Ecol. Res., 21, 165-173. 


\section{Appendix}

Appendix 1. Total of 78 different aquatic habitats along with station numbers (St. No.), station names (St. Name), codes of the habitat types (Hatyp), dissolved oxygen (DO, mg. $\mathrm{L}^{-1}$ ), electrical conductivity (EC, $\mu \mathrm{S} . \mathrm{cm}^{-1}$ at $25^{\circ} \mathrm{C}$ ), percent oxygen saturation $(\% \mathrm{~S})$, water temperature $\left(T_{\mathrm{w}},{ }^{\circ} \mathrm{C}\right)$, air temperature $\left(T_{\mathrm{a}},{ }^{\circ} \mathrm{C}\right)$, salinity (Sal., ppt), redox potential (SHE, mV), and altitude (Alt., m) are shown along with coordinates (latitude and longitude) and sampling dates (Date). Abbreviations include five different groups of habitat types as: A, Creek (creek, stream, river); B, Other (reedbed, waterpit and slough); C, Lake (lake and dam lake); D, Spring; E, Pond (pond, pool and through).

\begin{tabular}{|c|c|c|c|c|c|c|c|c|c|c|c|c|c|c|}
\hline & & & & & & & & & & & & & & \\
\hline No. & St. Name & Hatyp & DO & $\mathrm{EC}$ & $\% \mathrm{~S}$ & $T_{w}$ & $T_{\mathrm{a}}$ & Sal & $\mathrm{pH}$ & SHE & Alt. & Latitude & Longitude & Date \\
\hline 1 & Sabri Bey creek & $\mathrm{A}$ & 5.93 & 625.00 & 87.30 & 19.10 & 26.10 & 0.10 & 8.17 & 118.835 & 1715 & $38^{\circ} 59^{\prime} 12^{\prime \prime} \mathrm{N}$ & $43^{\circ} 45^{\prime} 62^{\prime \prime} \mathrm{E}$ & 06.07 .20 \\
\hline 2 & Bilici Mermer creek & A & 4.44 & 656.00 & 59.50 & 18.90 & 26.10 & 0.10 & 8.65 & 97.965 & 1713 & $9^{\circ} 00^{\prime} 25^{\prime \prime} \mathrm{N}$ & $43^{\circ} 45^{\prime} 10^{\prime \prime} \mathrm{E}$ & 5.07 .20 \\
\hline 3 & Kadak water pit & B & 5.44 & & 81.90 & 25.90 & 26.10 & 0.10 & 8.59 & & 1728 & $39^{\circ} 00^{\prime} 71^{\prime \prime} \mathrm{N}$ & $43^{\circ} 45^{\prime} 06^{\prime \prime} \mathrm{E}$ & 0.01 .20 \\
\hline 4 & Fat & A & 6.34 & 615.00 & 89.10 & 22.60 & 26.10 & 0.20 & 8.63 & 91.56 & 1730 & $38^{\circ} 59^{\prime} 71^{\prime \prime N}$ & 5'79"Е & 0.07 .20 \\
\hline 5 & Gökhan Bey creek & A & 5.26 & 625.00 & 78.00 & 23.80 & 26.10 & 0.10 & 8.75 & 87.78 & 1734 & $3 " \mathrm{~N}$ & $04 " \mathrm{E}$ & 6.07 .200 \\
\hline 6 & Muradiye dam 1 & $\mathrm{C}$ & 7.07 & 656.00 & 93.90 & 18.60 & 26.10 & 0.10 & 8.44 & 107.16 & 1745 & l'00"N & $57 " \mathrm{E}$ & 200 \\
\hline 7 & Muradiye dam 2 & $\mathrm{C}$ & 6.86 & 622.00 & 99.60 & 23.50 & 26.10 & 0.10 & 8.76 & 85.975 & 1732 & '99"N & 54"E & 7.200 \\
\hline 8 & Çerkez spring & $\mathrm{D}$ & 0.28 & 283.00 & 4.01 & 13.00 & & 0.00 & 7.32 & & 1725 & & 9"E & 200 \\
\hline 9 & $\mathrm{M}$ & A & 7.65 & 649.00 & 01.20 & & & & 8.42 & & 1727 & & & 00 \\
\hline 10 & Aş̧ & A & 7.52 & 589.00 & 3.50 & 25.00 & 26.10 & .10 & 8.85 & 77 & 1685 & 6"N & 1"E & 00 \\
\hline 11 & $\mathrm{Çel}$ & 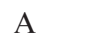 & 6.73 & 631.00 & 6.90 & 3.80 & & 0 & 8.57 & & 1688 & "N & 6"E & \\
\hline 12 & $\mathrm{Ke}$ & E & 7.35 & 640.00 & 6.40 & 2.90 & & 0 & 8.64 & & 1697 & "N & 2"E & \\
\hline 13 & & I & .70 & 00 & 3.00 & 3.70 & & .00 & 9.36 & & 1675 & "N & 8"E & \\
\hline 14 & $\overline{\mathrm{I}} \mathrm{dr}$ & L & 10 & 341.00 & 95.50 & 5.70 & & .00 & 8.02 & 45 & 1674 & $3 " \mathrm{~N}$ & $0 " \mathrm{E}$ & \\
\hline 15 & Kö & A & 75 & 647.00 & 125.10 & 1.60 & 26.10 & .10 & 8.44 & 21 & 1664 & $" \mathrm{~N}$ & 7"E & \\
\hline 16 & $\mathrm{Ka}$ & $\mathrm{E}$ & 58 & 658.00 & 88.20 & 20.70 & & .10 & 7.98 & 95 & 1668 & $" \mathrm{~N}$ & $8 " \mathrm{E}$ & \\
\hline 17 & & $\mathrm{E}$ & .72 & 645.00 & 86.50 & 1.10 & & 0.10 & 8.02 & & 1672 & "N & 3"E & \\
\hline 18 & & $\mathrm{E}$ & .41 & 652.00 & 87.60 & 0.50 & & 0.10 & 7.93 & & 1663 & & $1 " \mathrm{E}$ & \\
\hline 19 & & ( & 96 & 28.20 & 01.40 & 3.50 & & 0 & & & & & & \\
\hline 20 & $\mathrm{Jal}$ & $\mathrm{C}$ & 98 & 10 & & 50 & & 0 & & & 1663 & & $3 " \mathrm{E}$ & \\
\hline 21 & Lak & ( & 6.21 & 26.90 & 00.50 & 23.20 & & 7.30 & & & 1661 & & $2 " \mathrm{E}$ & \\
\hline 22 & Arne & $\mathrm{E}$ & 3.26 & 239.00 & 55.80 & 23.60 & & 0.00 & 7.12 & & 1674 & & 4"E & 200 \\
\hline 23 & & 5 & 3.38 & & & & & & 7.12 & & 1671 & & 5"E & \\
\hline 24 & & c & 6.64 & & & & & & & & 1667 & & & \\
\hline 25 & & $\mathrm{~L}$ & & & & & & & & & & & & \\
\hline 26 & & $\mathrm{~L}$ & & & & & & & & & & & & \\
\hline 27 & & $\mathrm{E}$ & & & & & & & & & & & & \\
\hline 28 & & I & 46 & & & & & & & & & & & \\
\hline 29 & & I & & & & & & & & & & & "E & \\
\hline 30 & & $\mathrm{I}$ & 22 & 0 & & & & & & & & & 7"E & 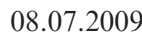 \\
\hline 31 & & $\mathrm{H}$ & & & & 0 & & & & & 18 & & $0 " \mathrm{E}$ & \\
\hline 32 & & I & 6 & & & 22.10 & & & & & 1744 & & 3"E & 08 \\
\hline 33 & & $\mathrm{r}$ & 7 & & 61 & 10 & & & & & 1772 & & 1"E & - \\
\hline 34 & & I & & & & 0 & & & & & 1781 & & $1 " \mathrm{E}$ & 200 \\
\hline 35 & & A & & & & & & & & & & & 8"E & 200 \\
\hline 36 & & 1 & & & & & & & & & & & 5"E & 00 \\
\hline 37 & & E & & & & 70 & & & & & 1919 & & $9 " \mathrm{E}$ & 00 \\
\hline 38 & & $\mathrm{E}$ & & & & 25.80 & & & & & 1920 & & $2 " E$ & 00 \\
\hline 39 & & $\mathrm{E}$ & 4.52 & & & 21.20 & & & 8.34 & & 1917 & & $4 " \mathrm{E}$ & 200 \\
\hline 40 & & $\mathrm{E}$ & 3.65 & & & 25.70 & & & 8.93 & & 1926 & 3"N & $26 " \mathrm{E}$ & 09. \\
\hline 41 & & $\mathrm{D}$ & 4.10 & & & & & & & & 1923 & & $8 " \mathrm{E}$ & 200 \\
\hline 42 & & A & & & & & & & & & 1927 & & $51 " \mathrm{E}$ & \\
\hline 43 & & $\mathrm{D}$ & & & & & & & & & 2774 & & $2 " \mathrm{E}$ & \\
\hline 44 & & $\mathrm{D}$ & & & & & & & & & & & & \\
\hline 45 & & $\Gamma$ & & & & & & & & & 2791 & & & \\
\hline 46 & & $\mathrm{D}$ & & & & & & & & & 2889 & & & \\
\hline 47 & & $\mathrm{D}$ & & & & & & & & & 2803 & & $2 " \mathrm{E}$ & \\
\hline 48 & & t & & & & & & & & & 1689 & & 9"E & \\
\hline 49 & & $A$ & & & & & & & & & 1691 & & 3"E & 200 \\
\hline 50 & & F & & & & & & & & & & & 2"E & 12.07 .20 \\
\hline 51 & & I & & & & & & & & & & & & \\
\hline 20 s & & & & & & & & & & & 280 & & $0 " \mathrm{E}$ & \\
\hline 53 & & L & & & & & & & & & 2290 & & 1"E & \\
\hline 54 & Bin & $\mathrm{D}$ & 4.08 & & & 11.00 & & 0.00 & 7.27 & 177 & 2229 & $93 " \mathrm{~N}$ & 78"E & 12.07 .200 \\
\hline 55 & Kö & $\mathrm{D}$ & 5.02 & & 45.70 & 9.00 & & 0.00 & 8.15 & 187.2 & 2235 & $0 " \mathrm{~N}$ & $43^{\circ} 48^{\prime} 78^{\prime \prime} \mathrm{E}$ & 12.07 .20 \\
\hline 50 & Piraşit puddle & $\mathrm{E}$ & 6.30 & 190.00 & 99.60 & 25.70 & 29.80 & 0.00 & 8.33 & 107.245 & 2211 & $38^{\circ} 54^{\prime} 95^{\prime \prime} \mathrm{N}$ & $43^{\circ} 49^{\prime} 61^{\prime \prime} \mathrm{E}$ & 3.07 . \\
\hline
\end{tabular}


Appendix 1. (continued.)

\begin{tabular}{|c|c|c|c|c|c|c|c|c|c|c|c|c|c|c|}
\hline & & & & & & & & & & & & & & \\
\hline No. & St. Name & Hatyp & DO & EC & $\% \mathrm{~S}$ & $T_{w}$ & $T_{\mathrm{a}}$ & Sal & $\mathrm{pH}$ & SHE & Alt. & Latitude & Longitude & Date \\
\hline 57 & Sürüyol creek & $\mathrm{A}$ & 4.82 & 447.00 & 72.70 & 22.20 & 29.80 & 0.00 & 8.49 & 100.62 & 2202 & $38^{\circ} 54^{\prime} 99^{\prime \prime} \mathrm{N}$ & $43^{\circ} 49^{\prime} 45^{\prime \prime} \mathrm{E}$ & 13.07 .2009 \\
\hline 58 & Yumaklı puddle & B & 3.80 & 189.00 & 58.30 & 25.60 & 29.80 & 0.00 & 8.64 & 87.71 & 2039 & $38^{\circ} 55^{\prime} 56^{\prime \prime} \mathrm{N}$ & $43^{\circ} 47^{\prime} 92^{\prime \prime} \mathrm{E}$ & 13.07.2009 \\
\hline 59 & Anzaf creek & A & 4.50 & 144.00 & 69.70 & 29.20 & 29.80 & 0.10 & 9.49 & 32.97 & 1708 & $38^{\circ} 56^{\prime} 19^{\prime \prime} \mathrm{N}$ & $43^{\circ} 45^{\prime} 90^{\prime \prime} \mathrm{E}$ & 13.07.2009 \\
\hline 60 & Ute fountain basin & B & 2.45 & 643.00 & 38.60 & 28.50 & 29.80 & 0.10 & 8.18 & 111.025 & 1684 & $38^{\circ} 56^{\prime} 57^{\prime \prime} \mathrm{N}$ & $43^{\circ} 45^{\prime} 09^{\prime \prime} \mathrm{E}$ & 13.07.2009 \\
\hline 61 & Kızılkilis puddle & $\mathrm{E}$ & 4.25 & 499.00 & 71.10 & 31.30 & 29.80 & 0.10 & 8.80 & 72.305 & 1677 & $38^{\circ} 57^{\prime} 01^{\prime \prime} \mathrm{N}$ & $43^{\circ} 45^{\prime} 65^{\prime \prime} \mathrm{E}$ & 13.07.2009 \\
\hline 62 & Yusuf Bey creek & A & 4.88 & 509.00 & 76.60 & 28.10 & 29.80 & 0.10 & 8.82 & 74.885 & 1680 & $38^{\circ} 57^{\prime} 05^{\prime \prime} \mathrm{N}$ & $43^{\circ} 45^{\prime} 69^{\prime \prime} \mathrm{E}$ & 13.07.2009 \\
\hline 63 & Rezak Bey creek & A & 3.21 & 512.00 & 47.10 & 23.60 & 29.80 & 0.10 & 8.49 & 97.71 & 1674 & $38^{\circ} 57^{\prime} 18^{\prime \prime} \mathrm{N}$ & $43^{\circ} 45^{\prime} 26^{\prime \prime} \mathrm{E}$ & 13.07.2009 \\
\hline 64 & İncesu creek & A & 2.66 & 169.00 & 39.30 & 25.80 & 29.80 & 0.20 & 8.01 & 123.78 & 1672 & $39^{\circ} 00^{\prime} 31^{\prime \prime} \mathrm{N}$ & $43^{\circ} 28^{\prime} 28^{\prime \prime} \mathrm{E}$ & 13.07.2009 \\
\hline 65 & İşkurumu creek & A & 4.13 & 213.00 & 41.20 & 24.90 & 29.80 & 0.10 & 7.95 & 128.965 & 1675 & $39^{\circ} 00^{\prime} 33^{\prime \prime} \mathrm{N}$ & $43^{\circ} 20^{\prime} 55^{\prime \prime} \mathrm{E}$ & 13.07.2009 \\
\hline 66 & Lake Van site 5 & $\mathrm{C}$ & 2.99 & 28.30 & 43.60 & 24.50 & 27.60 & 17.60 & 10.06 & 6.025 & 1661 & $38^{\circ} 59^{\prime} 88^{\prime \prime} \mathrm{N}$ & $33 " \mathrm{E}$ & 14.07.2009 \\
\hline 67 & Yeşil Ero & A & 5.72 & 293.00 & 34.10 & 12.50 & 27.60 & 0.10 & 8.05 & 132 & 1694 & $0 " \mathrm{~N}$ & $5 " \mathrm{E}$ & 2009 \\
\hline 68 & $\mathrm{M}$ & A & 4.82 & 611 & 57.20 & 15 & 27.60 & 0.10 & 8.24 & 137 & 1817 & $5 " \mathrm{~N}$ & 7"E & 2009 \\
\hline 69 & terfall 3 & A & 6.13 & 592 & 48.10 & 15 & 27.60 & 0.10 & 8.02 & 14 & 1792 & $0 " \mathrm{~N}$ & 1"E & .2009 \\
\hline 70 & Zoza & A & 5.63 & 590 & 61.20 & 20.10 & 27.60 & 10 & 8.13 & 130 & 1813 & N & $2 " E$ & 2009 \\
\hline 71 & Zoza & A & 5.21 & 578 & 63.70 & 22.30 & 27.60 & 0.10 & 7.91 & 117.755 & 1806 & "N & $3 " \mathrm{E}$ & 2009 \\
\hline 72 & Zoza & A & 6.09 & 618.00 & 58.60 & 19.60 & 27.60 & 0.10 & 8.01 & 126.91 & 1798 & $39^{\circ}$ & $2 " \mathrm{E}$ & 2009 \\
\hline 73 & Sıncık puddle & $\mathrm{E}$ & 6.45 & 671.00 & 52.00 & 24.10 & 27.60 & 0.10 & 7.53 & 126.685 & 1831 & $39^{\circ} 03^{\prime} 63^{\prime \prime} \mathrm{N}$ & $43^{\circ} 41^{\prime} 52^{\prime \prime} \mathrm{E}$ & 14.07.2009 \\
\hline 74 & Irrigation canal & B & 4.86 & 523.00 & 49.60 & 19.80 & 27.60 & 0.10 & 8.42 & 132.88 & 1823 & $39^{\circ} 01^{\prime} 31^{\prime \prime N}$ & $43^{\circ} 41^{\prime} 36^{\prime \prime} \mathrm{E}$ & 14.07.2009 \\
\hline 75 & Zarbun puddle & $\mathrm{E}$ & 4.53 & 534.00 & 72.30 & 23.10 & 27.60 & 0.10 & 8.14 & 123.435 & 1779 & $39^{\circ} 03^{\prime} 00^{\prime \prime} \mathrm{N}$ & $43^{\circ} 10^{\prime} 00^{\prime \prime} \mathrm{E}$ & 14.07.2009 \\
\hline 76 & Lake Aşağ 1 & $\mathrm{C}$ & 5.96 & 487.00 & 39.80 & 24.20 & 27.60 & 0.10 & 8.23 & 137.82 & 1781 & $39^{\circ} 00^{\prime} 11^{\prime \prime} \mathrm{N}$ & $43^{\circ} 45^{\prime} 17^{\prime \prime} \mathrm{E}$ & 14.07.2009 \\
\hline 77 & Erşat creek & A & 3.97 & 603.00 & 48.70 & 18.90 & 27.60 & 0.10 & 7.83 & 134.665 & 1801 & $39^{\circ} 03^{\prime} 42^{\prime \prime} \mathrm{N}$ & $43^{\circ} 23^{\prime} 27^{\prime \prime E}$ & 14.07.2009 \\
\hline 78 & Lake Van site 6 & $\mathrm{C}$ & 5.92 & 31.1 & 40.2 & 13.4 & 27.60 & 16.9 & 10.20 & 16.34 & 1672 & $38^{\circ} 69^{\prime} 08^{\prime \prime} \mathrm{N}$ & $43^{\circ} 21^{\prime} 51^{\prime \prime E}$ & 14.07.2009 \\
\hline
\end{tabular}

Appendix 2. Station numbers and species codes (Code) of 29 species found from 57 sampling sites during this study.

\begin{tabular}{|c|c|c|}
\hline Code & Species name & Station numbers \\
\hline$\overline{\mathrm{CC}}$ & C. candida & $11,12,21,57$ \\
\hline $\mathrm{CM}$ & C. muelleri & 54 \\
\hline $\mathrm{CN}$ & C. neglecta & $7,18,49,53,55$ \\
\hline $\mathrm{CL}$ & C. lindneri & 3 \\
\hline $\mathrm{CV}$ & Cypridopsis vidua & 28,60 \\
\hline $\mathrm{CP}$ & C. pubera & $2,28,29,60$ \\
\hline DS & Dolerocypris sinensis & 60 \\
\hline EV & Eucypris virens & 28,51 \\
\hline FF & Fabaeformiscandona fabaeformis & 18 \\
\hline HI & H. incongruens & $\begin{array}{l}1-8,16,17,25,26,29,31,32 \\
38,40,49-54,59-63,69,71\end{array}$ \\
\hline HS & H. salina & 3,50 \\
\hline IB & I. bradyi & $\begin{array}{l}1-8,11-13,21,25,26,28,29,32 \\
34-38,40,41,48,49,51-53,62\end{array}$ \\
\hline IG & I. gibba & 3 \\
\hline II & I. inermis & $4,9,16,34,35,39$, \\
\hline LM & L. mirabilis & $19,20,24$ \\
\hline LI & L. inopinata & $10,19,36,66,78$ \\
\hline PK & Physocypria kraepelini & 18 \\
\hline PR & Potamocypris variegata & 60 \\
\hline PV & P. villosa & $7,9,11,12,36,40,54,58,67,69,77$ \\
\hline $\mathrm{PF}$ & P. fulva & 53 \\
\hline PZ & P. zenkeri & $7,13,17,18,36,37,62,73$ \\
\hline PA & P. albicans & $2,6,29,53$ \\
\hline $\mathrm{PC}$ & P. compressa & 7 \\
\hline PS & P. semicognita & $3,28,60$ \\
\hline $\mathrm{PO}$ & Psychrodromus fontinalis & 54,55 \\
\hline SF & Stenocypria fischeri & 28 \\
\hline TL & T. laevis & 14 \\
\hline TS & T. serrata & 1,2 \\
\hline ES & Eucypris sp., & $7,28,52,53$ \\
\hline
\end{tabular}


Appendix 3. SEM photographs of species: 1, Candona candida; 2, Heterocypris incongruens; 3, Candona lindneri; 4, Cypris pubera; 5, Candona neglecta; 6, Potamocypris variegata; 7, Prionocypris zenkeri; 8, Stenocypria fischeri. Scale bar: $100 \mu \mathrm{m}$.

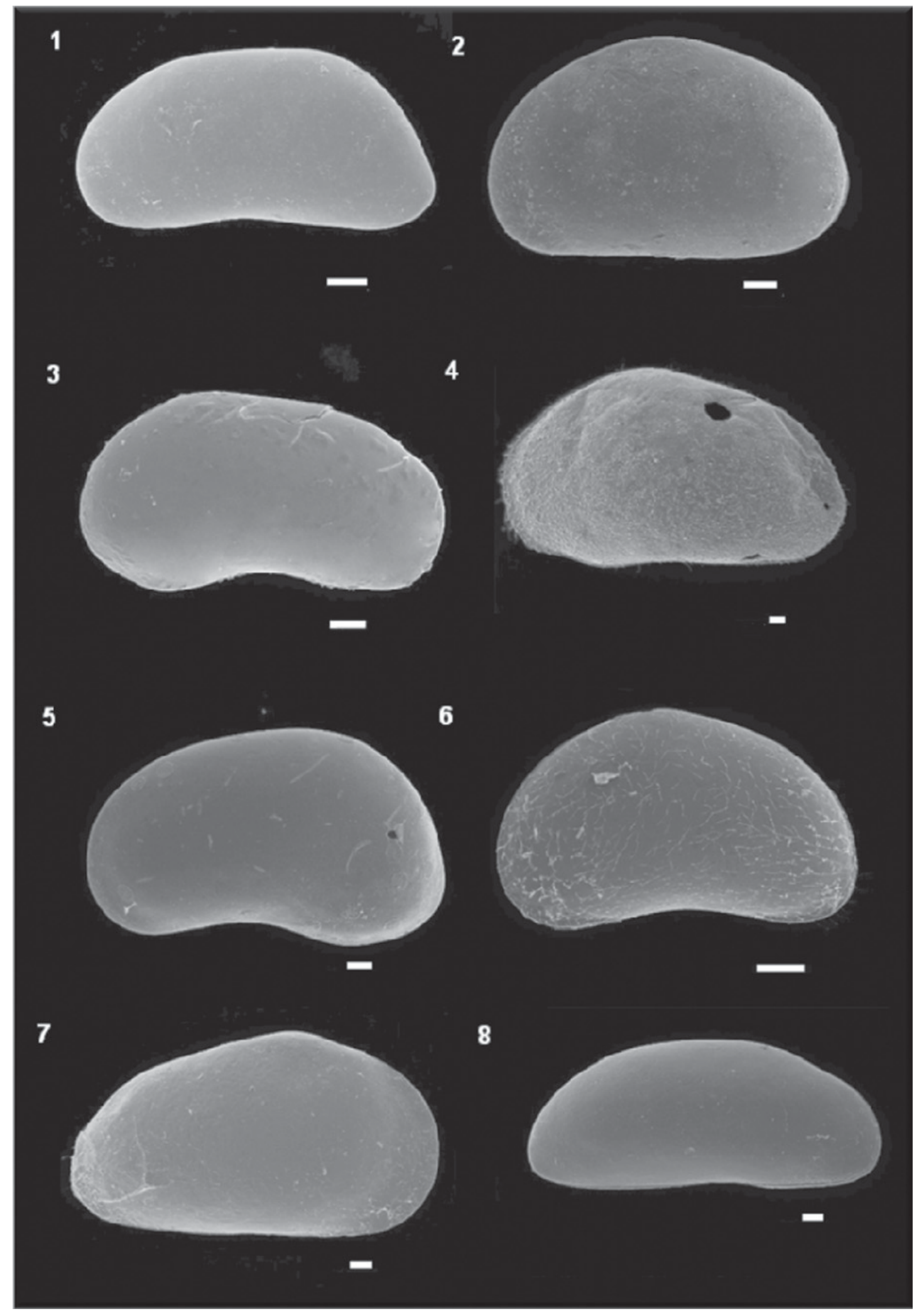


Appendix 4. SEM photographs of species. 1, Eucypris cf. sp.; 2, Cypridopsis vidua; 3, Fabaeformiscandona fabaeformis; 4, Heterocypris salina; 5, Ilyocypris bradyi; 6, Limnocythere inopinata; 7, Leucocythere mirabilis; 8, Potamocypris fulva. Scale bar: $100 \mu \mathrm{m}$.

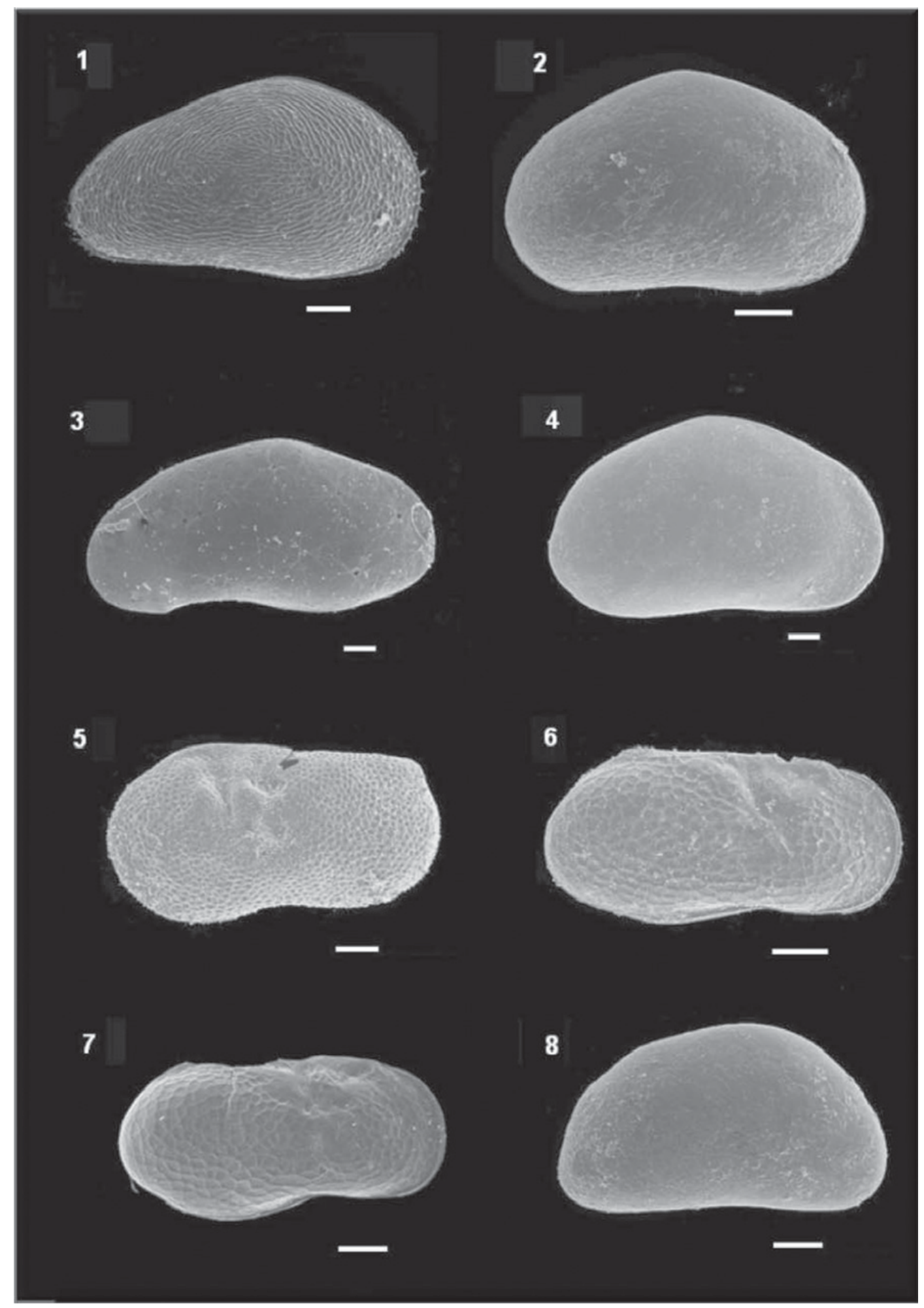

